JIIA, VOLUME 8 No. 1, FEBRUARI 2020

\title{
ANALISIS PREFERENSI, KEPUASAAN DAN LOYALITAS KONSUMEN TERHADAP KERIPIK PISANG DAN SINGKONG DI SENTRA AGROINDUSTRI KERIPIK KOTA BANDAR LAMPUNG
}

\author{
(Analysis of Preferences, Satisfaction and Consumers Loyalty on Banana and Cassava Chips at Sentra \\ Agroindustry Keripik in Bandar Lampung City) \\ Grace Virginie Agatha, Teguh Endaryanto, Ani Suryani \\ Jurusan Agribisnis, Fakultas Pertanian, Universitas Lampung, J1. Prof. Dr. Soemantri Brodjonegoro No. 1 \\ Bandar Lampung 35141, e-mail: teguh.endaryanto@fp.unila.ac.id
}

\begin{abstract}
The aims of this research are to analyze consumer's preferences, satisfaction, and loyalty of banana and cassava chips at chips agroindustry centers in Bandar Lampung. The agro industries were chosen purposively. There were 70 respondents taken by using accidental sampling. Data were collected in MayJune 2018 and analyzed descriptively by using Customer Satisfaction Index (CSI) and loyalty pyramid method (switcher buyer, habitual buyer, satisfied buyer, liking the brand buyer, and committed buyer). The results of this research showed that the attributes of banana and cassava chips which become the consumers preferences were low prices, good taste, crispy texture, pleasant scent, harder to get, and attractive packaging. The satisfaction levels of the consumers of banana and cassava chips were both classified as satisfying and loyal consumers.
\end{abstract}

Key words: banana, cassava, chips, consumers, satisfaction

\section{PENDAHULUAN}

Indonesia merupakan negara agraris dimana pembangunan di bidang pertanian menjadi prioritas utama karena Indonesia merupakan salah satu negara yang sebagian besar penduduknya bermata pencaharian di bidang pertanian. Sektor pertanian memberikan kontribusi dalam perekonomian penduduk Indonesia seperti menyediakan bahan baku industri, menyediakan lapangan kerja dan menjadi sumber pendapatan. Salah satu strategi pengembangan yang harus dimiliki Indonesia adalah kebijakan pembangunan yang menjaga keterkaitan antara sektor pertanian dengan sektor industri dalam bentuk pengembangan agroindustri.

Provinsi Lampung merupakan salah satu provinsi di Indonesia yang perekonomiannya bertumpu pada sektor pertanian. Berdasarkan BPS Provinsi Lampung (2016), dua kontribusi terbesar terhadap pembentukan PDRB Provinsi Lampung tahun 2016 terdapat pada sektor pertanian, kehutanan dan perikanan yaitu sebesar 31,54 persen dan sektor industri pengolahan sebesar 18,83 persen.Untuk mencapai struktur ekonomi yang seimbang diperlukan keterkaitan antara sektor pertanian dan sektor industri pengolah atau agroindustri, keterkaitan ini terlihat dengan adanya perkembangan pengolahan hasil pertanian melalui agroindustri. Agroindustri merupakan rangkaian kegiatan agribisnis berbasis pertanian yang saling berkaitan dalam suatu sistem produksi, pengolahan, distribusi, pemasaran dan berbagai kegiatan atau jasa penunjangnya. Kegiatan agroindustri dapat menghasilkan produk pangan dan atau non pangan.

Berdasarkan data dari Dinas Koperasi Provinsi Lampung (2017), bidang usaha agribisnis memiliki jumlah kedua terbanyak sebesar 6.445 UMKM, kemudian bidang usaha fashion sebesar 1.514 UMKM, bidang usaha otomotif sebesar 1.502 UMKM, bidang usaha teknologi internet sebesar 957 UMKM, bidang usaha pendidikan sebesar 250 UMKM, dan jumlah UMKM terbanyak terdapat pada bidang usaha kuliner yaitu sebesar 8.254 UMKM.

Salah satu makanan kuliner yang terdapat di Provinsi Lampung adalah keripik. Adapun macam-macam produk keripik antara lain keripik pisang, keripik singkong, klanting, keripik ubi jalar, keripik buah, dan olahan dari jagung. Umumnya keripik pisang terbuat dari jenis pisang kepok dikarenakan jenis pisang ini memiliki kandungan padatan yang cukup tinggi sehingga sangat sesuai untuk membuat keripik. Macammacam produk keripik tersebut memiliki banyak rasa diantaranya rasa coklat, susu, keju, manis, melon, durian dan lain-lain. Adanya penambahan cita rasa yang beragam maka perlu untuk diketahui 
bahwa rasa apa yang paling disukai oleh konsumen sesuai dengan preferensi konsumen tersebut. Preferensi adalah kecenderungan dalam memilih sesuatu dibandingkan yang lainnya karena sesuai dengan keinginan. Setelah konsumen memilih rasa, perlu diketahui bahwa apakah konsumen merasa puas dengan rasa yang tersebut. Menurut Kotler (2002), kepuasan konsumen adalah tingkat perasaan seseorang setelah membandingkan kinerja (atau hasil) yang ia rasakan dengan harapannya. Bila kinerja melebihi harapan, maka konsumen akan merasa puas, dan sebaliknya, bila kinerja tidak sesuai harapan, maka akan kecewa.

Menurut Daryanto dan Setyobudi (2014), kepuasan konsumen merupakan suatu penilaian emosional dari konsumen setelah konsumen menggunakan suatu produk, dimana harapan dan kebutuhan konsumen terpenuhi. Konsumen yang merasa puas belum tentu merupakan konsumen yang loyal, akan tetapi konsumen yang loyal merupakan konsumen yang merasa puas terhadap produk tersebut.

Griffin dan Ebert (2003), menyatakan bahwa tingkat loyalitas konsumen terbentuk dari tercapainya tingkat kepuasan yang dirasakan oleh konsumen sehubungan dengan kegiatan konsumen mengonsumsi atau menggunakan suatu barang atau jasa. Kepuasan dan loyalitas merupakan salah satu aspek dalam menentukan perkembangan dan pertumbuhan suatu perusahaan.

Salah satu jenis agroindustri yang terdapat di Kota Bandar Lampung adalah agroindustri sentra keripik yang berada di Jalan Pagar Alam Gg PU Kelurahan Gunung Agung, Kecamatan Langkapura, Bandar Lampung. Agroindustri ini merupakan salah satu agroindustri yang terkenal di Kota Bandar Lampung yang membuatmacammacam keripik. Agroindustri keripik di sentra agroindustri keripik di Kota Bandar Lampung berjumlah 32 kios yang berjajar untuk mengolah dan memasarkan keripik pisang dengan berbagai merek di kawasan sentra agroindustri keripik.

Penelitian ini bertujuan untuk menganalisis preferensi, kepuasaan dan loyalitas konsumen terhadap keripik pisang dan singkong di sentra agroindustri keripik di Kota Bandar Lampung.

\section{METODE PENELITIAN}

Penelitian ini dilakukan di sentra agroindustri keripik di Kota Bandar Lampung menggunakan metode survai. Pemilihan lokasi dilakukan secara sengaja (purposive). Responden penelitian ini berjumlah 70 orang dari tujuh agroindustri keripik. Setiap agroindustri diambil sepuluh orang sebagai responden menggunakan accidental sampling. Pengambilan data dilakukan pada bulan Mei-Juni 2018.

Data yang digunakan dalam penelitian ini adalah data primer dan data sekunder. Data primer dalam penelitian ini adalah identitas konsumen, preferensi konsumen, kepuasaan konsumen serta loyalitas konsumen yang seluruhnya diperoleh dari wawancara langsung dengan responden, sedangkan data sekunder yang digunakan berupa jumlah UMKM di Provinsi Lampung, komposisi gizi pisang, singkong, keripik pisang dan keipik singkong yang masing-masing diperoleh dari BPS, Dinas Koperasi Provinsi Lampung dan Direktorat Gizi Departemen Kesehatan Republik Indonesia.

Metode yang digunakan untuk menganalisis preferensi konsumen adalah deskriptif kuantitatif dengan kategorisasi. Untuk mengetahui tingkat kesukaan konsumen terhadap atribut intrinsik dan atribut ekstrinsik keripik digunakan data rating dengan aturan penilaian skala likert tiga butir. Atribut diperoleh dari uji validitas dan reliabilitas. Atribut intrinsik keripik meliputi rasa, aroma, tekstur, dan kemasan produk, sedangkan atribut ekstrinsik meliputi harga dan kemudahan memperoleh. Jawaban disediakan sesuai dengan kriteria atribut yang telah ditentukan. Jawaban yang paling tidak sesuai dengan keinginan responden diberi skor satu, sedangkan jawaban yang paling sesuai dengan keinginan responden diberi skor tiga.

Kepuasaan konsumen dianalisis menggunakan alat analisis Customer Satisfaction Index (CSI). Penentuan kepuasan diukur dengan menggunakan seperangkat pertanyaan dengan menggunakan skala likert dengan lima alternative jawaban yakni sangat memuaskan (skor 5), memuaskan (skor 4), cukup memuaskan (skor 3), kurang memuaskan (skor 2), dan tidak memuaskan (skor 1). Tingkat kepuasan konsumen dilihat berdasarkan enam atribut yakni atribut harga, rasa, aroma, tekstur, kemudahan memperoleh dan kemasan produk.

Uji validitas dan reliabilitas merupakan pengujian yang dilakukan untuk mengukur sah atau valid tidaknya suatu kuesioner dengan menguji jawaban dari 30 responden. Berdasarkan hasil yang diperoleh tingkat kepentingan dan kinerja dari atribut harga, rasa, aroma, tekstur dan kemudahan memperoleh sudah valid dan reliabel. Menurut 
Sufren dan Natanael (2013), nilai validitas dapat dikatakan baik, jika nilai corrected item dari total correlation bernilai lebih dari 0,2 . Berbeda dengan uji validitas, uji reliabilitas dilakukan untuk mengetahui reliabilitas dari atribut-atribut yang diajukan pada responden dalam kuesioner. Apabila digunakan pada lokasi dan waktu yang berbeda, maka akan memperoleh hasil yang sama. Suatu instrumen dapat dikatakan reliabel, apabila nilai Cronbach's Alpha 0,6 - 0,8 (Sufren dan Natanael 2013)

Menurut Supranto (2006), Customer Satisfaction Index (CSI) merupakan salah satu metode yang digunakan untuk mengetahui tingkat kepuasan pelanggan secara keseluruhan dengan memperhatikan tingkat kepentingan dari atributatribut suatu produk atau jasa. Nilai maksimum untuk CSI adalah 100 persen dengan rentang nilai menurut yakni sangat puas $(81 \%-100 \%)$, puas (66\%-80\%), cukup puas (51\%-65\%), kurang puas (35\%-50\%), dan tidak puas (0\%-34\%). Berikut merupakan rumus perhitungan CSI:

$$
\mathrm{CSI}=\frac{\mathrm{T}}{5(\mathrm{Y})} \times 100 \%
$$

Keterangan :

$$
\begin{aligned}
\mathrm{CSI}= & \text { Customer Satisfaction Index } \\
(\mathrm{T})= & \text { Total seluruh skor } \\
(\mathrm{Y})= & \text { Total seluruh nilai harapan (kepentingan) } \\
5 & \begin{array}{l}
\text { Nilai maksimum yang digunakan dalam } \\
\text { skala pengukuran }
\end{array}
\end{aligned}
$$

Tingkat loyalitas konsumen dianalisis dengan menggunakan piramida loyalitas yakni berdasarkan switcher buyer, habitual buyer, satisfied buyer, liking the brand buyer dan commited buyer.

Switcher adalah konsumen yang sensitif terhadap perubahan harga, sehingga pada tingkatan loyalitas ditempatkan pada urutan paling bawah diukur dengan mengajukan beberapa pertanyaan menggunakan skala likert dengan lima respon yaitu (1) tidak pernah, (2) jarang, (3) kadangkadang, (4) sering dan (5) sangat sering. Switcher buyer adalah responden yang menjawab sering dan sangat sering.

Habitual buyer adalah responden yang dikategorikan sebagai pembeli yang puas dengan produk yang dikonsumsinya. Beberapa pertanyaan diukur dengan menggunakan skala likert dengan lima respon yaitu (1) sangat tidak setuju, (2) tidak setuju, (3) ragu-ragu, (4) setuju, dan (5) sangat setuju. Responden yang termasuk habitual buyer yaitu yang menjawab setuju dan sangat setuju.

Satisfied buyer menggambarkan seberapa besar presentase responden yang puas, meskipun mungkin saja mereka memindahkan pembeliannya ke merek lain dengan menanggung switching cost (biaya peralihan) yang terkait dengan waktu, uang, atau resiko kinerja yang melekat dengan tindakan mereka beralih merek. Beberapa pertanyaan diukur dengan menggunakan skala likert dengan lima respon yaitu sangat (1) sangat tidak puas, (2) tidak puas, (3) cukup puas, puas (4), dan sangat puas (5). Responden yang termasuk satisfied buyer adalah yang menjawab puas dan sangat puas.

Liking the brand menggambarkan seberapa besar persentase responden yang membeli keripik pisang dan singkong yang sungguh-sungguh menyukai merek tersebut. Beberapa pertanyaan diukur dengan menggunakan skala likert dengan lima respon yaitu (1) sangat tidak suka, (2) tidak suka, (3) biasa saja, (4) suka, dan (5) sangat suka. Responden yang termasuk liking the brand adalah responden yang menjawab suka dan sangat suka.

Committed Buyer menggambarkan seberapa besar persentase responden yang membeli keripik pisang dan singkong yang merupakan pelanggan yang setia. Beberapa pertanyaan diukur dengan menggunakan skala likert dengan lima respon yaitu (1) sangat tidak setuju, (2) tidak setuju, (3) ragu-ragu, (4) setuju, dan (5) sangat setuju. Responden yang termasuk committed buyer adalah responden yang menjawab setuju dan sangat setuju.

\section{HASIL DAN PEMBAHASAN}

\section{Karakteristik Responden}

Dalam penelitian terdapat 40 responden perempuan dan 30 responden laki-laki. Sebanyak 57,14 persen responden yang membeli keripik berada pada kisaran usia 17-23 tahun. Seluruh responden pernah menerima pendidikan formal dengan tingkat pendidikan terendah SMP dan tertinggi S1. Tingkat pendidikan terbanyak berada pada tingkat SMA dan pekerjaan responden yang memiliki persentase tertinggi adalah mahasiswa yaitu sebanyak 29 orang dengan persentase sebesar 41,43 persen dibandingkan dengan pekerjaan lainnya. 


\section{Preferensi Konsumen}

Preferensi seseorang dapat menunjukkan rasa suka seseorang terhadap suatu barang tertentu yang dipengaruhi oleh karakteristik produk, karekteristik individu, dan karakteristik lingkungan. Terdapat enam atribut yang diteliti dalam penelitian ini yaitu atribut harga, rasa, aroma, tekstur, kemudahan memperoleh dan kemasan produk.Pada atribut harga responden menilai bahwa harga keripik pisang dan singkong yang dijual adalah sedang. Hal ini dikarenakan harga keripik yang dijual masih terjangkau dan menurut responden yang dijumpai, mereka memang sudah terbiasa membeli keripik karena faktor suka sehingga apabila harga keripik yang dijual mengalami kenaikan responden akan tetap membeli.

Berdasarkan hasil penelitian yang telah dilakukan, konsumen keripik di sentra agroindustri keripik di Kota Bandar Lampung menganggap rasa keripik pisang dan singkong enak. Pada atribut ini tidak ada satu pun responden yang tidak suka terhadap rasa keripik pisang atau pun singkong.

Umumnya konsumen menyukai keripik pisang rasa coklat, kemudian urutan kedua rasa keju dan pada urutan ketiga konsumen menyukai keripik pisang rasa susu, sedangkan pada keripik singkong yaitu rasa balado, kemudian urutan kedua rasa jagung manis dan pada urutan ketiga konsumen menyukai keripik singkong rasa asin. Rasa keripik singkong yang disukai konsumen di Kota Bandar Lampung pada urutan pertama yaitu rasa balado yang mungkin disebabkan oleh rata-rata masyarakat di Kota Bandar Lampung cenderung menyukai makanan pedas. Amalia, Endro dan Damanik (2012) menyatakan bahwa tambahan bumbu pedas sering kali menjadikan seseorang merasa ketagihan.Data mengenai kategori rasa yang paling disukai konsumen dapat dilihat pada Tabel 1 .

Penilaian responden terhadap atribut tekstur yang dirasakan konsumen saat mengkonsumsi keripik adalah renyah, sedangkan aroma keripik beraroma sedap. Dalam hal atribut kemudahan memperoleh, konsumen keripik pisang dan singkong sebagian besar menempuh jarak yang jauh yaitu lebih dari $3 \mathrm{~km}$ dan pada atribut kemasan, responden menganggap bahwa kemasan produk keripik pisang dan singkong menarik.Selengkapnya preferensi atribut dengan persentase tertinggi disajikan pada Gambar 1.
Tabel 1. Kategori rasa yang paling disukai konsumen

\begin{tabular}{lrrrr}
\hline \multirow{2}{*}{ Varian rasa } & \multicolumn{2}{c}{$\begin{array}{c}\text { Responden } \\
\text { (orang) }\end{array}$} & \multicolumn{2}{c}{$\begin{array}{c}\text { Persentase } \\
(\%)\end{array}$} \\
\cline { 2 - 5 } Coklat & K.P & \multicolumn{1}{c}{ K.S } & K.P & \multicolumn{1}{c}{ K.S } \\
Susu & 49 & 0 & 23,33 & 0,00 \\
Keju & 27 & 0 & 12,86 & 0,00 \\
Sapipanggang & 34 & 0 & 16,19 & 0,00 \\
Barbeque & 18 & 0 & 8,57 & 0,00 \\
Melon & 19 & 18 & 9,05 & 8,57 \\
Strawberry & 17 & 0 & 8,10 & 0,00 \\
Mocca & 6 & 0 & 2,86 & 0,00 \\
Kopi & 6 & 0 & 2,86 & 0,00 \\
Manis & 2 & 0 & 0,95 & 0,00 \\
Asin & 11 & 0 & 5,24 & 0,00 \\
Original & 1 & 36 & 0,48 & 17,14 \\
Green tea & 0 & 31 & 0,00 & 14,76 \\
Balado & 7 & 0 & 3,33 & 0,00 \\
Jagung manis & 9 & 55 & 4,29 & 26,19 \\
Jagung pedas & 0 & 44 & 0,00 & 20,95 \\
Durian & 0 & 26 & 0,00 & 12,38 \\
Total & 4 & 0 & 1,90 & 0,00 \\
Keterangan: & 210 & 210 & 100,00 & 100,00 \\
K.P = Keripik Pisang & & & & \\
K.S = Keripik Singkong & & & & \\
& & & &
\end{tabular}

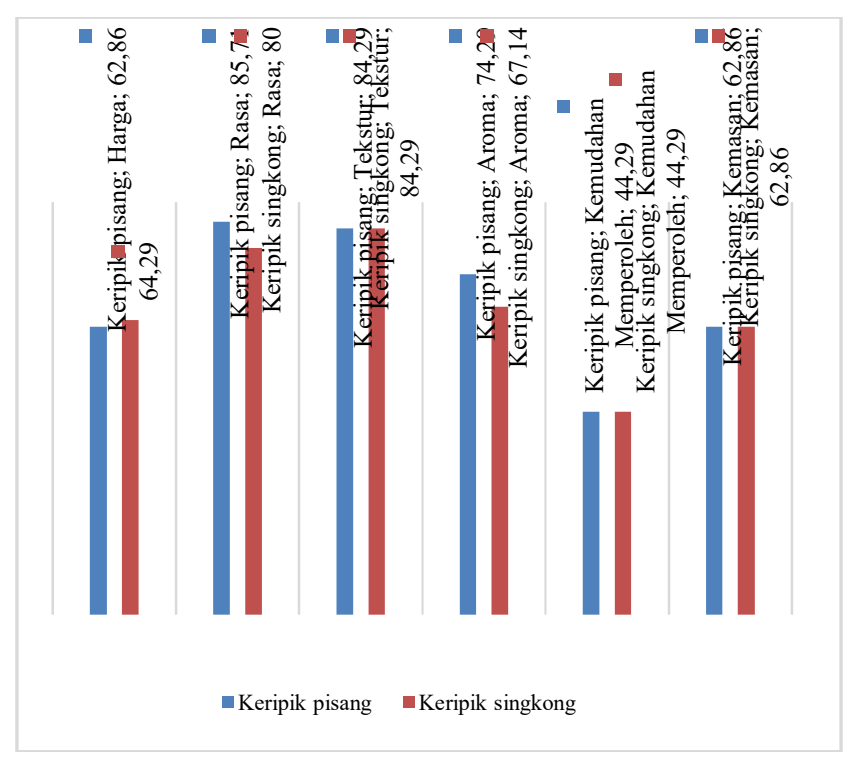

Gambar 1. Atribut dengan persentase tertinggi

Pada Gambar 1, dalam memilih keripik baik keripik pisang maupun singkong, atribut yang mendapat persentase tertinggi oleh konsumen yaitu rasa, tekstur, aroma, harga, kemasan dan kemudahan memperoleh produk. Hasil penelitian ini berbeda dengan penelitian Azhari (2016) dalam keripik ubi jalar di Kota Medan. Perbedaannya terdapat pada atribut aroma yaitu atribut aroma lebih unggul dibandingkan atribut tekstur yaitu sebesar 9,125 persen sedangkan pada penelitian ini atribut tesktur lebih unggul dibandingkan dengan aroma yaitu sebesar 84,29 persen. 


\section{Tingkat Kepuasan Konsumen}

Berdasarkan hasil analisis tingkat kepuasan dengan menggunakan metode Customer Satisfaction Index (CSI) didapatkan nilai sebesar 71,2 persen yang berarti sebagian besar konsumen telah merasa puas. Hasil analisis tingkat kepuasan ini sejalan dengan penelitian Efendi, Silvia dan Wijaya (2018) mengenai Analisis Kinerja dan Kepentingan Pada Atribut Keripik Bledang Bengkulu Sebagai Upaya Pengukuran Kualitas Kepuasan Pada Industri Makanan yang didapatkan nilai sebesar 0,93 dan dikategorikan sangat puas. Walaupun konsumen telah merasa puas, pihak agroindustri harus meningkatkan dan tetap menjaga kualitas serta mutu produk, sehingga dapat terus memberikan kepuasan terhadap konsumen.

\section{Tingkat Loyalitas Konsumen}

Loyalitas konsumen dapat diukur dengan menggunakan alat analisis berupa piramida loyalitas. Piramida loyalitas terdiri dari lima tingkatan yaitu switcher buyer, habitual buyer, satisfied buyer, liking thebrand, dan committed buyer.

\section{Analisis Switcher Buyer}

Switcher buyer adalah konsumen keripik pisang dan singkong di sentra agroindustri keripik yang akan tetap membeli keripik walaupun harga keripik naik. Biasanya switcher buyer adalah konsumen yang lebih sensitif terhadap perubahan harga.

Berdasarkan Tabel 2 dapat dilihat bahwa switcher buyer yang diperoleh pada penelitian ini adalah 61,43 persen, artinya sebagian besar dari konsumen akan tetap membeli keripik pisang di sentra agroindustri keripik jika terjadi perubahan harga. Rata-rata penilaian konsumen terhadap switcher buyer adalah 3,63 dan berada pada rentang skala 3,40-4,19 yang artinya konsumen tetap sering membeli keripik pisang walaupun sering terjadi perubahan harga.

Berdasarkan Tabel 3 dapat dilihat bahwa switcher buyer yang diperoleh pada keripik singkong sama dengan switcher buyer yang diperoleh oleh keripik pisang, artinya sebagian besar dari konsumen akan tetap membeli keripik singkong di sentra agroindustri keripik jika terjadi perubahan harga. Rata-rata penilaian konsumen terhadap switcher
Tabel 2. Perhitungan switcher buyer terhadap produk keripik pisang

\begin{tabular}{lcrrr}
\hline Jawaban & x & f & fx & \multicolumn{1}{c}{$\%$} \\
\hline 1. Tidak pernah & 1 & 1 & 1 & 0,39 \\
2. Jarang & 2 & 3 & 6 & 2,36 \\
3. Kadang-Kadang & 3 & 23 & 69 & 27,17 \\
4. Sering & 4 & 37 & 148 & 58,27 \\
5. Sangat Sering & 5 & 6 & 30 & 11,81 \\
\hline Rata-rata & & & 3,63 \\
\hline Switcher buyer & & \\
Keterangan untuk Tabel 2, 3, 4, 5, 6, 7, 8, 9, 10, dan 11: \\
x = Bobot masing-masing jawaban \\
f = Jumlah responden yang menjawab \\
fx = Hasil perkalian antara bobot jawaban dan jumlah responden \\
$\% \quad=$ Persentase responden yang menjawab
\end{tabular}

Tabel 3. Perhitungan switcher buyer terhadap produk keripik singkong

\begin{tabular}{lrrrr}
\hline Jawaban & $\mathrm{x}$ & $\mathrm{f}$ & $\mathrm{fx}$ & \multicolumn{1}{c}{$\%$} \\
\hline 1. Tidak pernah & 1 & 1 & 1 & 0,39 \\
2. Jarang & 2 & 4 & 8 & 3,11 \\
3. Kadang-Kadang & 3 & 22 & 66 & 25,68 \\
4. Sering & 4 & 33 & 132 & 51,36 \\
5. Sangat Sering & 5 & 10 & 50 & 19,46 \\
\hline Rata-rata & & & & 3,67 \\
\hline Switcher buyer & & & & 61,43 \\
\hline
\end{tabular}

Berdasarkan Tabel 3 dapat dilihat bahwa switcher buyer yang diperoleh pada keripik singkong sama dengan switcher buyer yang diperoleh oleh keripik pisang, artinya sebagian besar dari konsumen akan tetap membeli keripik singkong di sentra agroindustri keripik jika terjadi perubahan harga. Rata-rata penilaian konsumen terhadap switcher buyer adalah 3,67 dan berada pada rentang skala 3,40-4,19 yang artinya konsumen sering membeli walaupun terjadi perubahan harga.

\section{Analisis Habitual Buyer}

Pada bagian habitual buyer, konsumen yang ada pada kategori ini merupakan konsumen yang sudah merasakan kepuasan dalam mengonsumsi produk. Konsumen habitual buyer mengkonsumsi suatu merek produk hanya berdasarkan kebiasaan. Hasil perhitungan habitual buyer produk keripik pisang disajikan pada Tabel 4.

Tabel 4 menunjukkan bahwa nilai habitual buyer sebesar 51,43 persen dan nilai rata-rata penilaian konsumen sebesar 3,51. Nilai ini berada pada rentang rentang skala 3,41-4,20 yang berarti konsumen termasuk dalam kategori setuju bahwa alasan membeli keripik singkong di sentra agroindustri Kota Bandar Lampung karena faktor terbiasa. 
Tabel 4. Perhitungan habitual buyer terhadap produk keripik pisang

\begin{tabular}{lrrrr}
\hline Jawaban & X & \multicolumn{1}{c}{$\mathrm{f}$} & \multicolumn{1}{c}{$\mathrm{fx}$} & \multicolumn{1}{c}{$\%$} \\
\hline 1. Sangat tidak setuju & 1 & 0 & 0 & 0,00 \\
2. Tidak setuju & 2 & 4 & 8 & 3,25 \\
3. Ragu-ragu & 3 & 30 & 90 & 36,59 \\
4. Setuju & 4 & 32 & 128 & 52,03 \\
5. Sangat setuju & 5 & 4 & 20 & 8,13 \\
\hline Rata-rata & & & & 3,51 \\
\hline Habitual buyer & & & & 51,43 \\
\hline
\end{tabular}

Tabel 5. Perhitungan habitual buyer terhadap produk keripik singkong

\begin{tabular}{lrrrr}
\hline Jawaban & \multicolumn{1}{l}{ x } & \multicolumn{1}{c}{ f } & \multicolumn{1}{c}{ x } & \multicolumn{1}{c}{$\%$} \\
\hline 1.Sangat tidak setuju & 1 & 0 & 0 & 0,00 \\
2. Tidak setuju & 2 & 4 & 8 & 3,16 \\
3. Ragu-ragu & 3 & 25 & 75 & 29,64 \\
4. Setuju & 4 & 35 & 140 & 55,34 \\
5. Sangat setuju & 5 & 6 & 30 & 11,86 \\
\hline Rata-rata & & & & 3,61 \\
\hline Habitual buyer & & & & 58,57 \\
\hline
\end{tabular}

Pada Tabel 5 menunjukkan bahwa nilai habitual buyer sebesar 58,57 persen dan nilai rata-rata penilaian responden sebesar 3,61. Artinya konsumen termasuk dalam kategori setuju membeli keripik singkong karna terbiasa dengan nilai berada pada rentang skala 3,41-4,20 di sentra agroindustri Kota Bandar Lampung.

Hal ini berarti konsumen keripik pisang dan singkong telah merasa puas terhadap produk dan mereka akan melakukan pembelian secara terusmenerus. Berdasarkan hasil wawancara, hal lain yang membuat konsumen biasa membeli produk keripik di sentra agroindustri di Kota Bandar Lampung adalah lokasi agroindustri yang memiliki banyak pilihan outlet keripik.

\section{Analisis Satisfied Buyer}

Satisfied buyer menggambarkan seberapa besar jumlah konsumen yang puas, meskipun mungkin saja mereka memindahkan pembeliannya ke merek lain dengan menanggung switching cost (biaya peralihan) yang terkait dengan waktu, uang, atau resiko kinerja yang melekat dengan tindakan mereka beralih merek. Responden yang termasuk satisfied buyer adalah yang menjawab "puas" dan "sangat puas". Hasil perhitungan satisfied buyer produk keripik pisang disajikan pada Tabel 6 .

Berdasarkan Tabel 6 dapat dilihat bahwa satisfied buyer yang diperoleh pada penelitian sebesar 40 persen konsumen yang membeli produk keripik pisang di sentra agroindustri keripik merasa puas.
Tabel 6. Perhitungan satisfied buyer terhadap produk keripik pisang

\begin{tabular}{lrrrr}
\hline Jawaban & \multicolumn{1}{c}{$\mathrm{x}$} & \multicolumn{1}{c}{$\mathrm{f}$} & \multicolumn{1}{c}{$\mathrm{x}$} & \multicolumn{1}{c}{$\%$} \\
\hline 1. Sangat tidak puas & 1 & 0 & 0 & 0,00 \\
2. Tidak puas & 2 & 3 & 6 & 2,47 \\
3. Cukup puas & 3 & 39 & 117 & 48,15 \\
4. Puas & 4 & 20 & 80 & 32,92 \\
5. Sangat puas & 5 & 8 & 40 & 16,46 \\
\hline Rata-rata & & & & 3,47 \\
\hline Satisfied buyer & & & & 40,00 \\
\hline
\end{tabular}

Rata-rata penilaian konsumen terhadap satisfied buyer adalah 3,47 yang berada pada rentang skala 3,41- 4,20 yang artinya konsumen menemukan kepuasan setelah membeli produk keripik pisang di sentra agroindustri keripik.

Data perhitungan satisfied buyer produk keripik singkong disajikan pada Tabel 7 . Tabel 7 menunjukkan bahwa nilai satisfied buyer sebesar 51,43 persen dan nilai rata-rata penilaian responden sebesar 3,49. Nilai ini berada pada rentang rentang skala 3,41-4,20 yang berarti konsumen termasuk dalam kategori puas setelah membeli keripik singkong di sentra agroindustri keripik di Kota Bandar Lampung

\section{Analisis Liking The Brand Buyer}

Pada bagian liking the brand buyer, konsumen yang berada pada kategori ini merupakan konsumen yang benar-benar menyukai merek suatu produk. Para pembeli pada tingkat ini disebut sahabat merek, karena terdapat perasaan emosional dalam menyukai merek. Pilihan mereka terhadap suatu merek dilandasi pada suatu asosiasi, seperti simbol, rangkaian pengalaman dalam menggunakannya, atau kesan kualitas yang tinggi.

Tabel 8 menunjukkan bahwa nilai liking the brand buyer keripik pisang sebesar 58,57 persen, sedangkan pada Tabel 9 nilai liking the brand buyer keripik singkong sebesar 60 persen. Nilai rata-rata penilaian konsumen keripik pisang

Tabel 7. Perhitungan satisfied buyer terhadap produk keripik singkong

\begin{tabular}{lcrrr}
\hline Jawaban & \multicolumn{1}{l}{ x } & \multicolumn{1}{c}{$\mathrm{f}$} & \multicolumn{1}{c}{$\mathrm{x}$} & \multicolumn{1}{c}{$\%$} \\
\hline 1. Sangat tidak puas & 1 & 1 & 1 & 0,41 \\
2. Tidak puas & 2 & 4 & 8 & 3,28 \\
3. Cukup puas & 3 & 29 & 87 & 35,66 \\
4. Puas & 4 & 32 & 128 & 52,46 \\
5. Sangat puas & 5 & 4 & 20 & 8,20 \\
\hline Rata-rata & & & & 3,49 \\
\hline Satisfied buyer & & & & 51,43 \\
\hline
\end{tabular}


Tabel 8. Perhitungan liking the brand buyer terhadap produk keripik pisang

\begin{tabular}{lrrrr}
\hline Jawaban & x & \multicolumn{1}{c}{ f } & \multicolumn{1}{c}{ fx } & \multicolumn{1}{c}{$\%$} \\
\hline 1. Sangat tidak suka & 1 & 0 & 0 & 0,00 \\
2. Tidak suka & 2 & 1 & 2 & 0,76 \\
3. Biasa saja & 3 & 28 & 84 & 32,06 \\
4. Suka & 4 & 29 & 116 & 44,27 \\
5. Sangat suka & 5 & 12 & 60 & 22,90 \\
\hline Rata-rata & & & & 3,74 \\
\hline Liking the brand buyer & & & & 58,57 \\
\hline
\end{tabular}

sebesar 3,74 dan nilai rata-rata penilaian konsumen keripik singkong sebesar 3,64 yang berada pada rentang skala 3,40-4,19 yang berarti konsumen menyukai keripik pisang di sentra agroindustri keripik di Kota Bandar Lampung.

Hal ini berarti agroindustri harus menjaga dan mempertahankan kualitas dan mutu keripik agar konsumen tidak berpaling ke produk lainnya.Adapun 7 brand agroindustri dalam penelitian ini adalah agroindustri Latif Jaya, Rona Jaya, Shinta, Merry, Riska, Asa, Suheri dan Wagiman. Data perhitungan liking the brand buyer produk keripik singkong disajikan pada Tabel 9.

\section{Analisis Commited Buyer}

Committed buyer adalah golongan konsumen yang merupakan pelanggan setia dari pembelian produk keripik. Responden yang termasuk committed buyer adalah responden yang menjawab "setuju" dan "sangat setuju" pada kuesioner.

Tabel 9. Perhitungan liking the brand buyer terhadap produk keripik singkong

\begin{tabular}{lrrrr}
\hline Jawaban & \multicolumn{1}{c}{ x } & \multicolumn{1}{c}{ fx } & \multicolumn{1}{c}{$\%$} \\
\hline 1. Sangat tidak Suka & 1 & 1 & 1 & 0,39 \\
2. Tidak suka & 2 & 4 & 8 & 3,14 \\
3. Biasa saja & 3 & 23 & 69 & 27,06 \\
4. Suka & 4 & 33 & 132 & 51,76 \\
5. Sangat suka & 5 & 9 & 45 & 17,65 \\
\hline Rata-rata & & & & 3,64 \\
\hline Liking the brand buyer & & & & 60,00 \\
\hline
\end{tabular}

Tabel 10. Perhitungan commited buyer terhadap produk keripik pisang

\begin{tabular}{lrrrr}
\hline Jawaban & \multicolumn{1}{c}{ x } & \multicolumn{1}{c}{ fx } & \multicolumn{1}{c}{$\%$} \\
\hline 1. Sangat tidak setuju & 1 & 0 & 0 & 0,00 \\
2. Tidak Setuju & 2 & 1 & 2 & 0,74 \\
3. Ragu-ragu & 3 & 23 & 69 & 25,65 \\
4. Setuju & 4 & 32 & 128 & 47,58 \\
5. Sangat Setuju & 5 & 14 & 70 & 26,02 \\
\hline Rata-rata & & & & 3,84 \\
\hline Commited buyer & & & & 65,71 \\
\hline
\end{tabular}

Berdasarkan Tabel 10 dan Tabel 11 dapat dilihat bahwa committed buyer yang diperoleh pada penelitian keripik pisang dan singkong sebesar 65,71 persen, artinya sebagian besar konsumen setuju untuk merekomendasikan dan mempromosikan produk keripik pisang dan singkong kepada orang lain atau dapat dikatakan sebagai konsumen yang loyal. Penghitungan committed buyer keripik singkong dapat dilihat pada Tabel 11. Data selengkapnya tentang loyalitas keripik pisang dan singkong disajikan paada Gambar 2 dan 3.

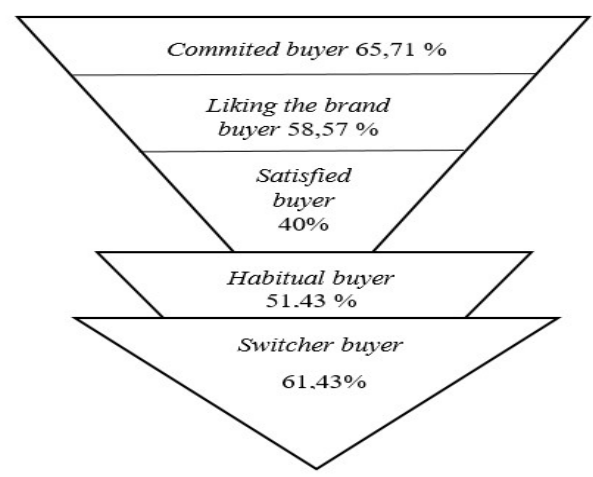

Gambar 2. Piramida loyalitas keripik pisang.

Pada Gambar 2 dan 3 terlihat bahwa bentuk piramida loyalitas dalam penelitian ini adalah piramida terbalik. Hal ini menunjukkan bahwa penelitian ini sesuai teori yaitu nilai committed buyer lebih besar dibandingkan nilai switcher buyer, artinya konsumen sudah loyal atau bersedia melakukan pembelian ulang serta merekomendasikan dan mempromosikan produk keripik pisang di sentra agroindustri Kota Bandar Lampung kepada orang lain.

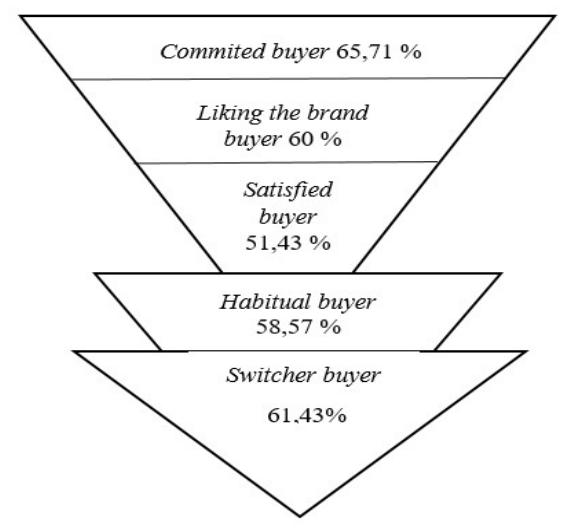

Gambar 3. Piramida loyalitas keripik singkong. 
Tabel 11. Perhitungan commited buyer terhadap produk keripik singkong

\begin{tabular}{lrrrr}
\hline Jawaban & x & \multicolumn{1}{c}{$\mathrm{f}$} & \multicolumn{1}{c}{$\mathrm{fx}$} & \multicolumn{1}{c}{$\%$} \\
\hline 1. Sangat tidak setuju & 1 & 0 & 0 & 0,00 \\
2. Tidak setuju & 2 & 6 & 12 & 4,49 \\
3. Ragu-ragu & 3 & 18 & 54 & 20,22 \\
4. Setuju & 4 & 29 & 116 & 43,45 \\
5. Sangat setuju & 5 & 17 & 85 & 31,84 \\
\hline Rata-rata & & & & 3,81 \\
\hline Commited buyer & & & & 65,71 \\
\hline
\end{tabular}

\section{KESIMPULAN}

Atribut keripik yang menjadi preferensi konsumen adalah harga murah, rasa enak, tekstur renyah, aroma sedap, jarak memperoleh dekat dan kemasan produk menarik. Konsumen keripik pisang dan singkong yang mengonsumsi produk keripik pisang dan singkong berada pada kriteria puas yaitu sebesar 75,24 persen keripik pisang dan 77,46 persen keripik singkong dan merupakan konsumen yang loyal dengan nilai commited buyer sebesar 65,71 persen.

\section{DAFTAR PUSTAKA}

Amalia L, Endro OP, dan Damanik MRM. 2012. Preferensi dan frekuensi konsumsi makanan jajanan pada anak sekolah dasar di Kecamatan Cijeruk Kabupaten Bogor. Jurnal Gizi dan Pangan, 7(2): 119-126. http://researchgate.net/publication/32197054 2. [15 Agustus 2018].
Azhari A. 2016. AnalisisPreferensi Konsumen Terhadap Keripik Ubi Jalar di Kota Medan. Skripsi. Universitas Sumatera Utara. Medan.

Azhari A. 2016. AnalisisPreferensi Konsumen Terhadap Keripik Ubi Jalar di Kota Medan. Skripsi. Universitas Sumatera Utara. Medan.

BPS [Badan Pusat Statistik] Propinsi Lampung. 2016. Produk Domestik Regional Bruto Provinsi Lampung Tahun 2016. Badan Pusat Statistik. Bandar Lampung. . 2016. Produk Domestik Regional Bruto Provinsi. Badan Pusat Statistik. Bandar Lampung.

Daryanto dan Setyobudi I . 2014. Konsumen dan Pelayanan Prima. Gava Media. Yogyakarta.

Dinas Koperasi Provinsi Lampung. 2017. Jumlah UMKM Provinsi Lampung. Dinas Koperasi Provinsi Lampung. Bandar Lampung.

Efendi Z, Silvia E, dan Wijaya RR. Analisis kinerja dan kepentingan pada atribut Keripik Bledang Bengkulu sebagai upaya pengukuran kualitas kepuasan pada industri makanan. Jurnal Agroindustri, 8(1) : $26-$ 33. https://ejournal.unib.ac.id/index.php/ agroindustri. [14 November 2018]

Griffin dan Ebert. 2003. Bisnis Jilid 1 Edisi Kedelapan. Erlangga. Jakarta.

Kotler P. 2002. Manajemen Pemasaran Jilid 1 Edisi Milenium. Prehallindo. Jakarta.

Sufren dan Natanael Y. 2013. Mahir Menggunakan SPSS secara Otodidak. PT Elex Media Komputindo. Jakarta.

Supranto J. 2006. Pengukuran Tingkat Kepuasan Pelanggan Untuk Menaikkan Pangsa Pasar. Penerbit Rineka Cipta. Jakarta. 